\title{
XXVIII. A new process for rendering platina malleable. Read before the Askesian Society in the Session 1804-5
}

\section{Alexander Tilloch}

To cite this article: Alexander Tilloch (1805) XXVIII. A new process for rendering platina malleable. Read before the Askesian Society in the Session 1804-5, Philosophical Magazine Series 1, 21:82, 175-175, DOI: 10.1080/14786440508676694

To link to this article: http://dx.doi.org/10.1080/14786440508676694

曲 Published online: 18 May 2009.

Submit your article to this journal $\pi$

Џ Article views: 2

Q View related articles $₫$ 


\section{[ $\begin{array}{lll}175 & \text { ] }\end{array}$}

XXVIII. A new Process for rendering Platina mallealle. By Alexanden Truzoch. Read before the Askesian Society in the Session 1804-5.

THE methods hitherto employed for bringing this metal into a malleable state, may be comprehended under one or other of the three following processes.

1. To dissolve the crude platina in nitro-muriatic acid, precipitate by muriate of ammonia, wash and dry the precipitate, and then expose it, mixed with arsenic, to such a degree of heat as may volatilize the latter, leaving the platina in a spungy form; which, by gentle hammering, and repeated exposures to a high degree of heat, is at length rendered solid and malleable.

2. To mix the pure precipitate with twice its weight of mercury, and bring the whole into the state of an amalgam, which is then moulded into the form of bars, and by exposure to heat freed from the mercury, and then hammered, gently at first, into a solid form.

3. To expose the precipitate per se in a crucible to such a heat as may agglutinate the particles, which are then brought into eloser union by gently pressing, and at last hammering the mass.

I purposely avoid a more minute detail of these processes, as they must be well known to all the members of this society; and will be in a great measure superseded by my new process, which is as follows.

Dissolve, precipitate, and wash the platina in the usual manner; and then, instead of mixing it with a volatile metal, or exposing it per se to heat in an earthen crucible, envelope the precipitate (previously heated to drive off the adhering ammonia) in a piece of platina, already malleable, and spread out by means of a flatting-mill. Nothing more is then necessary, but to expose repeatedly the malleable platina,and its contents; to a sufficient temperature, and hammering between each exposure, till the whole is brought into a compact state.

The best way to inclose the precipitate in the malleable platina is, by rolling up the latter into the form of a tube, filling this with the precipitate, well rammed in, and then closing the ends, by hammering them in, before exposure to the fire.

When a sufficient heat is obtained, apply the hammer at first only on the side where the malleable platina overlaps, not all round the tube. By this means its capacity is lessened, and the contents are soon welded, and brought into union with the tube, after which it may be worked into the form of a bar, or any other shape wanted. 